\title{
PENINGKATAN HASIL BELAJAR IPS MELALUI MODEL KOOPERATIF TIPE NHT SISWA KELAS V SDN 5 NGEMBALREJO
}

\author{
Naella Ichdatul Musdalifa, Murtono, Ika Oktavianti \\ Email: ellanaefersly@gmail.com \\ Program Studi Pendidikan Guru Sekolah Dasar \\ FKIP Universitas Muria Kudus
}

\begin{abstract}
The background of this research is the low students' achievement of social studies caused by the boredom felt by the students in learning social studies. The learning process done by the teacher is still conventional. The learning condition of social studies that tent to be boring causes the students feel difficult in learning social studies. Numbered Head Together is a learning method in which every student is given by number and from there a group is made, then, randomly, the teacher calls out the number from the students. Social studies is an integrated subject from various branches of social science.

This is a Classroom Action Research with qualitative and quantitative approaches, using Kemmis and Mc Taggart design which consist of 4 stages, there are: planning, action, observation, reflection.

The first condition of the students before the action achieved classical accomplishment by $32 \%$ with the average score 61,1 increased in the cycle I became $64 \%$ with the average 70,2 and in the cycle II increased to $88 \%$ with the average 73 ' 6 . The students' learning activity classically in the cycle I earned 2,45 average score with the category of good enough increased in the cycle II became 2,64 which is included good category. The teacher's skill also is having improvement, in the cycle I achieved 2,82 average score with the category of good, in the cycle II increased to 3,08 with the category of good.

Based on this research, the use of cooperative model NHT type can increase the students, achievement of social studies, whereas the students' evaluation score as the cognitive aspect, and the students' learning activity also the teacher's performance in the learning process as the affective and psychomotoric aspect. In this research, the writer recommend the students to be more active during the teaching and learning process. For the teacher, the learning process need to apply learning model to create an attractive and enjoyable learning environment.
\end{abstract}

Key Words: Social Studies Achievement, NHT

\begin{abstract}
ABSTRAK
Penelitian ini dilatarbelakangi hasil belajar IPS siswa yang rendah, dikarenakan siswa merasa bosan ketika mempelajari IPS. Proses pembelajaran yang dilakukan guru masih bersifat konvensional. Suasana belajar IPS yang cenderung membosankan menyebabkan siswa sulit mempelajari IPS. Numbered Heads Together adalah metode belajar dengan cara setiap siswa diberi nomor dan
\end{abstract}


dibuat suatu kelompok, kemudian secara acak, guru memanggil nomor dari siswa. IPS merupakan integrasi dari berbagai cabang ilmu-ilmu sosial.

Jenis penelitian ini adalah penelitian tindakan kelas dengan pendekatan kualitatif dan kuantitatif, menggunakan desain dari Kemmis dan Mc Taggart yang terdiri dari 4 tahap yaitu perencanaan, pelaksanaan, pengamatan dan refleksi.

Kondisi awal siswa sebelum melakukan tindakan mendapat ketuntasan klasikal sebesar 32\% dengan rata-rata 61,1 meningkat pada siklus I menjadi 64\% dengan rata-rata 70,2 dan pada siklus II meningkat menjadi $88 \%$ dengan rata-rata 73,6. Aktivitas belajar siswa secara klasikal pada siklus I mendapat rata-rata 2,45 dengan kategori cukup baik meningkat pada siklus II menjadi 2,64 dengan kategori baik. Keterampilan guru juga mengalami peningkatan, siklus I mendapatkan rata-rata 2,82 dengan kategori baik, pada siklus II meningkat menjadi 3,08 dengan kriteria baik.

Simpulan pada penelitian ini adalah menggunakan model kooperatif tipe NHT dapat meningkatkan hasil belajar IPS siswa, yaitu nilai evaluasi siswa sebagai aspek kognitif, dan aktivitas belajar siswa, serta aktivitas guru dalam pembelajaran sebagai aspek afektif dan psikomotor. Saran dalam penelitian ini bagi siswa diharapkan pada saat pembelajaran sebaiknya siswa harus lebih aktif selama proses pembelajaran berlangsung. Bagi guru proses pembelajaran perlu menerapkan model pembelajaran untuk menciptakan kondisi belajar yang menarik dan menyenangkan.

Kata Kunci: Hasil belajar IPS, NHT

\section{PENDAHULUAN}

\section{Latar Belakang Masalah}

Pendidikan merupakan suatu hal yang penting dalam menjadikan manusia yang berilmu, berbudaya, bertaqwa serta mampu menghadapi tantangan masa datang. Dengan pendidikan tersebut melahirkan peserta didik yang cerdas serta mempunyai kompetensi dan skill untuk dikembangkan ditengah-tengah masyarakat. Untuk mewujudkan hal demikian tidak terlepas dari faktor penentu dalam keberhasilan siswa dalam pendidikan.

Pada jenjang pendidikan dasar pemberian mata pelajaran IPS dimaksudkan untuk membekali siswa dengan pengetahuan, kemampuan praktis, agar mereka dapat menelaah, mempelajari dan mengkaji fenomenafenomena serta masalah sosial yang ada disekitar mereka. Melalui mata pelajaran IPS, siswa diarahkan untuk menjadi warga negara Indonesia yang demokratis, dan bertangggung jawab, serta warga dunia yang cita damai, melalui pemahaman terhadap pengetahuan dan kemampuannya di dalam berinteraksi secara positif dan 
aktif dengan lingkungannya. Tujuan tersebut membuat guru memiliki tanggung jawab besar untuk menggunakan pemikiran dan tenaga untuk dapat mengajarkan IPS dengan baik dan benar.

Menurut Trianto (2010: 171) Ilmu Pengetahuan Sosial (IPS) merupakan integrasi dari berbagai cabang ilmu-ilmu sosial, seperti sosiologi, sejarah, geografi ekonomi, politik, hukum dan budaya. Berdasarkan pengertian dan tujuan pembelajaran IPS tersebut, diperlukan tenaga guru yang profesional artinya mampu melakukan proses pembelajaran yang tepat dan terencana untuk mencapai hasil belajar siswa.

IPS sebagai salah satu mata pelajaran yang memiliki tujuan membekali siswa untuk mengembangkan penalaran di samping aspek nilai dan moral. Implementasinya, materi IPS hanya menekankan aspek pengetahuan yang berpusat pada guru dan hanya membentuk budaya menghafal, sehingga pengetahuan dan informasi yang diterima siswa sebatas produk hafalan. Pembelajaran IPS sangat menjenuhkan karena penyajiannya kurang menarik, bersifat monoton dan konvensional, hanya sekedar ceramah.

Berdasarkan hasil observasi dan wawancara dengan guru kelas di SDN 5 Ngembalrejo Bae Kudus, peneliti menemukan hasil pembelajaran IPS dari beberapa siswa pada ulangan harian yang hanya mencapai nilai 60 dengan jumlah siswa yang kurang dari KKM adalah 17 siswa. Penyebab belum optimalnya hasil belajar siswa pada mata pelajaran IPS di SDN 5 Ngembalrejo adalah kegiatan pembelajaran masih terpusat pada guru dan masih menggunakan metode ceramah. Sehingga mengakibatkan pembelajaran yang dilaksanakan terkesan hanya sebagai penyampaian materi saja tanpa terlihat adanya keaktifan siswa.

Peningkatan hasil belajar siswa dapat dilakukan dengan menciptakan situasi pembelajaran yang melibatkan siswa. Guru sebagai fasilitator dalam pembelajaran menggunakan berbagai model, metode/cara pembelajaran sesuai yang lebih melibatkan siswa. Menurut Suprijono (2013: 46) model pembelajaran adalah pola yang digunakan sebagai pedoman dalam merencanakan pembelajaran di kelas maupun toritorial. Pemilihan model dan strategi pembelajaran yang tepat dapat memudahkan guru dalam proses pembelajaran, karena pada hakikatnya 
guru bukan satu-satunya sumber informasi dan belajar siswa. Model pembelajaran kooperatif lebih membuat siswa aktif dalam pembelajaran.

Berdasarkan pada permasalahan tersebut untuk meningkatkan hasil belajar siswa SDN 5 Ngembalrejo, maka diperlukan untuk menciptakan kondisi pembelajaran yang inovatif, guru dituntut agar mampu mengelola kelas dalam proses pembelajaran yang memberikan rangsangan kepada siswa supaya lebih efektif dalam pembelajaran. Adapun upaya untuk meningkatkan hasil belajar siswa tersebut adalah menerapkan model pembelajaran kooperatif tipe NHT (Numbered Heads Together) dalam pembelajaran IPS. Dengan menggunakan model tersebut siswa dapat lebih aktif dalam pembelajaran, saat berdiskusi siswa tidak bergantung pada siswa yang lain dan saat mempresentasikan hasil diskusi kelompok siswa lebih antusias dan lebih aktif. Peran guru dalam pembelajaran IPS lebih memungkinkan terciptanya kondisi belajar yang kondusif seperti memberikan siswa kesempatan berperan aktif.

Dari latar belakang yang telah diuraikan, peneliti mengambil judul "Peningkatan Hasil Belajar IPS melalui Penerapan Model Kooperatif Tipe NHT Siswa Kelas V SDN 5 Ngembalrejo". Materi yang digunakan dalam pembelajaran yaitu keragaman suku dan budaya Indonesia. Model pembelajaran kooperatif adalah konsep yang lebih luas meliputi semua jenis kerja kelompok termasuk bentuk-bentuk yang lebih dipimpin oleh guru atau diarahkan oleh guru. Pembelajaran kooperatif dianggap lebih diarahkan oleh guru, dimana guru menetapkan tugas dan pertanyaan-pertanyaan serta menyediakan bahan-bahan dan informasi yang dirancang untuk membantu siswa menyelesaikan masalah yang dimaksud. Numbered Heads Together atau penomoran berfikir bersama merupakan jenis pembelajaran kooperatif yang dirancang untuk mempengaruhi pola interaksi siswa dan sebagai alternatif terhadap struktur kelas tradisional.

Berdasarkan latar belakang yang telah dikemukakan, secara umum masalah yang dirumuskan yakni "Apakah terjadi peningkatan keterampilan guru, aktivitas siswa dan hasil belajar IPS setelah diterapkan model kooperatif tipe NHT pada siswa kelas V SDN 5 Ngembalrejo?”. Tujuan penelitian ini adalah untuk menemukan seberapa besar peningkatan keterampilan guru, aktivitas siswa dan 
hasil belajar IPS setelah diterapkan model kooperatif tipe NHT pada siswa kelas V SDN 5 Ngembalrejo.

\section{KAJIAN PUSTAKA DAN HIPOTESIS TINDAKAN}

\section{Kajian Pustaka}

\section{Hasil Belajar}

Slameto (2010: 2) belajar ialah suatu proses usaha yang dilakukan seseorang untuk mempengaruhi suatu perubahan tingkah laku yang baru secara keseluruhan, sebagai hasil pengamatannya sendiri dalam interaksi dengan lingkungannya.

Trianto (2010: 16) belajar adalah perubahan pada individu yang terjadi melalui pengalaman, dan bukan karena pertumbuhan atau perkembangan tubuhnya atau karakteristik seseorang sejak lahir. Belajar merupakan kegiatan penting setiap orang, termasuk didalamnya belajar bagaimana seharusnya belajar (Aunurrahman, 2009: 33).

Purwanto (2013: 54) mengemukakan hasil belajar adalah perubahan perilaku yang terjadi setelah mengikuti proses belajar mengajar sesuai dengan tujuan pendidikan. Sedangkan Djamarah (2011: 176) faktor-faktor yang mempengaruhi proses dan hasil belajar yaitu faktor lingkungan, faktor instrumental, faktor fisiologis, dan faktor psikologis.

Dari paparan tersebut dapat disimpulkan bahwa hasil belajar merupakan hasil nilai yang diperoleh siswa dari hasil evaluasi setelah kegiatan proses pembelajaran yang sudah dicapai oleh setiap siswa dalam ranah kognitif, afektif dan psikomotor yang diperoleh sebagai akibat usaha kegiatan belajar dan dinilai dalam periode tertentu.

\section{IPS}

Trianto (2010: 171) Ilmu Pengetahuan Sosial (IPS) merupakan integrasi dari berbagai cabang ilmu-ilmu sosial, seperti sosiologi, sejarah, geografi ekonomi, politik, hukum dan budaya. IPS dirumuskan atas dasar realitas dan fenomena sosial yang mewujudkan satu pendekatan interdisipliner dari aspek dan 
cabang-cabang ilmu-ilmu sosiai (sosiologi, sejarah, geografi, ekonomi, politik, hukum, dan budaya).

Djahari dan Makmun (dalam Gunawan 2011: 17) "IPS atau studi sosial konsep-konsepnya merupakan konsep pilihan dari berbagai ilmu lalu dipadukan dan diolah secara didaktis-pedagogis sesuai dengan tingkat perkembangan siswa".

Trianto (2010: 176) tujuan utama Ilmu Pengetahuan Sosial ialah untuk mengembangkan potensi peserta didik agar peka terhadap masalah sosial yang terjadi di masyarakat, memiliki sikap mental positif terhadap perbaikan segala ketimpangan yang terjadi, dan terampil mengatasi setiap masalah yang terjadi sehari-hari, baik yang menimpa dirinya sendiri maupun yang menimpa masyarakat. Tujuan tersebut dapat dicapai manakala program-program pelajaran IPS di sekolah diorganisasikan secara baik.

Dari paparan tersebut dapat disimpulkan bahwa Ilmu Pengetahuan Sosial (IPS) adalah cabang ilmu sosial yang terdiri dari sosiologi, sejarah, geografi ekonomi, politik, hukum dan budaya. Sedangakan tujuan IPS sekolah dasar ialah untuk mencetak generasi yang berwawasan ilmu sosial serta konsep-konsep yang berkaitan dengan kehidupan masyarakat dan lingkungannya baik dari aspek kognisi, afeksi maupun psikomotor.

Penelitian ini memfokuskan peningkatan hasil belajar IPS kelas V SDN 5 Ngembalrejo pada ruang lingkup IPS “Sistem Sosial dan Budaya”. Terdapat pada Standar Kompetensi: 1. Menghargai berbagai peninggalan dan tokoh sejarah yang berskala nasional pada masa Hindu-Budha dan Islam, keragaman kenampakan alam dan suku bangsa, serta kegiatan ekonomi di Indonesia. Kompetensi Dasar: 1.4 Menghargai keragaman suku bangsa dan budaya di Indonesia.

\section{Pembelajaran Kooperatif}

Pembelajaran kooperatif adalah konsep yang lebih luas meliputi semua jenis kerja kelompok termasuk bentuk-bentuk yang lebih diarahkan oleh guru (Suprijono, 2013: 54).

Riyanto (2010: 267), pembelajaran kooperatif adalah model pembelajaran yang dirancang untuk membelajarkan kecakapan akademik (academic Skill), sekaligus keterampilan sosial (social skill) termasuk interpersonal skill. 
Sedangkan Solihatin (2011: 4) berpendapat bahwa pada dasarnya cooperative learning mengandung pengertian sebagai suatu sikap atau perilaku bersama dalam bekerja atau membantu di antara sesama dalam struktur kerja sama yang teratur dalam kelompok, yang terdiri dari dua orang atau lebih di mana keberhasilan kerja sangat dipengaruhi oleh keterlibatan dari setiap anggota kelompok itu sendiri.

Zamroni (2000) dalam Trianto (2010: 57) manfaat penerapan belajar kooperatif adalah dapat mengurangi kesenjangan pendidikan khususnya dalam wujud input pada level individual.

\section{Numbered Heads Together (NHT)}

Trianto (2010: 82), Numbered Heads Together atau penomoran berfikir bersama merupakan jenis pembelajaran kooperatif yang dirancang untuk mempengaruhi pola interaksi siswa dan sebagai alternatif terhadap struktur kelas tradisional.

Huda (2013: 130), NHT merupakan varian dari diskusi kelompok. Numbered Heads Together adalah metode belajar dengan cara setiap siswa diberi nomor dan dibuat suatu kelompok, kemudian secara acak, guru memanggil nomor dari siswa (Hamdani, 2011: 89).

Suprijono (2013: 92) tujuan pembelajaran tipe Numbered Heads Together (NHT) ini adalah agar peserta didik dapat menemukan jawaban pertanyaan sebagai pengetahuan yang utuh.

Dari beberapa pendapat dapat disimpulkan bahwa pengetian Numbered Heads Together (NHT) adalah model pembelajaran yang membagi siswa ke dalam beberapa kelompok kecil, hal ini ditujukan agar siswa dapat saling bekerjasama, saling membantu dan saling memotivasi dengan siswa lainnya, agar siswa dapat mencapai hasil yang maksimal dari pembelajaran tersebut.

\section{Keragaman Suku dan Budaya}

Setiadi, dkk (2006: 147) menyatakan keragaman adalah suatu kondisi dalam masyarakat di mana terdapat perbedaan-perbedaan dalam berbagai bidang, terutama suku bangsa dan ras, agama dan keyakinan, ideologi, adat kesopanan, serta situasi ekonomi. 
Koentjaraningrat (2009: 215), konsep yang tercakup dalam istilah "suku bangsa" adalah suatu golongan manusia yang terikat oleh kesadaran dan identitas akan "kesatuan kebudayaan".

Widagdho (2001: 21) mendefinisikan "Kebudayaan adalah keseluruhan sistem gagasan, tindakan dan hasil karya manusia untuk memenuhi kehidupannya dengan cara belajar, yang semuanya tersusun dalam kehidupan masyarakat.”

Ranjabar (2006: 75), kebudayaan Indonesia bukanlah sesuatu yang padu dan bulat, tetapi adalah sesuatu yang terjadi dari berbagai-bagai unsur suku bangsa. Di daerah Indonesia yang luas terdapat bermacam-macam kebudayaan, yang satu berbeda dari yang lain disebabkan oleh perjalanan yang berbeda.

\section{Kerangka Berpikir}

Fokus utama dalam penelitian ini adalah peningkatan hasil belajar IPS siswa pada kelas V. Kerangka berfikir tindakan di kelas digambarkan sebagai berikut. 


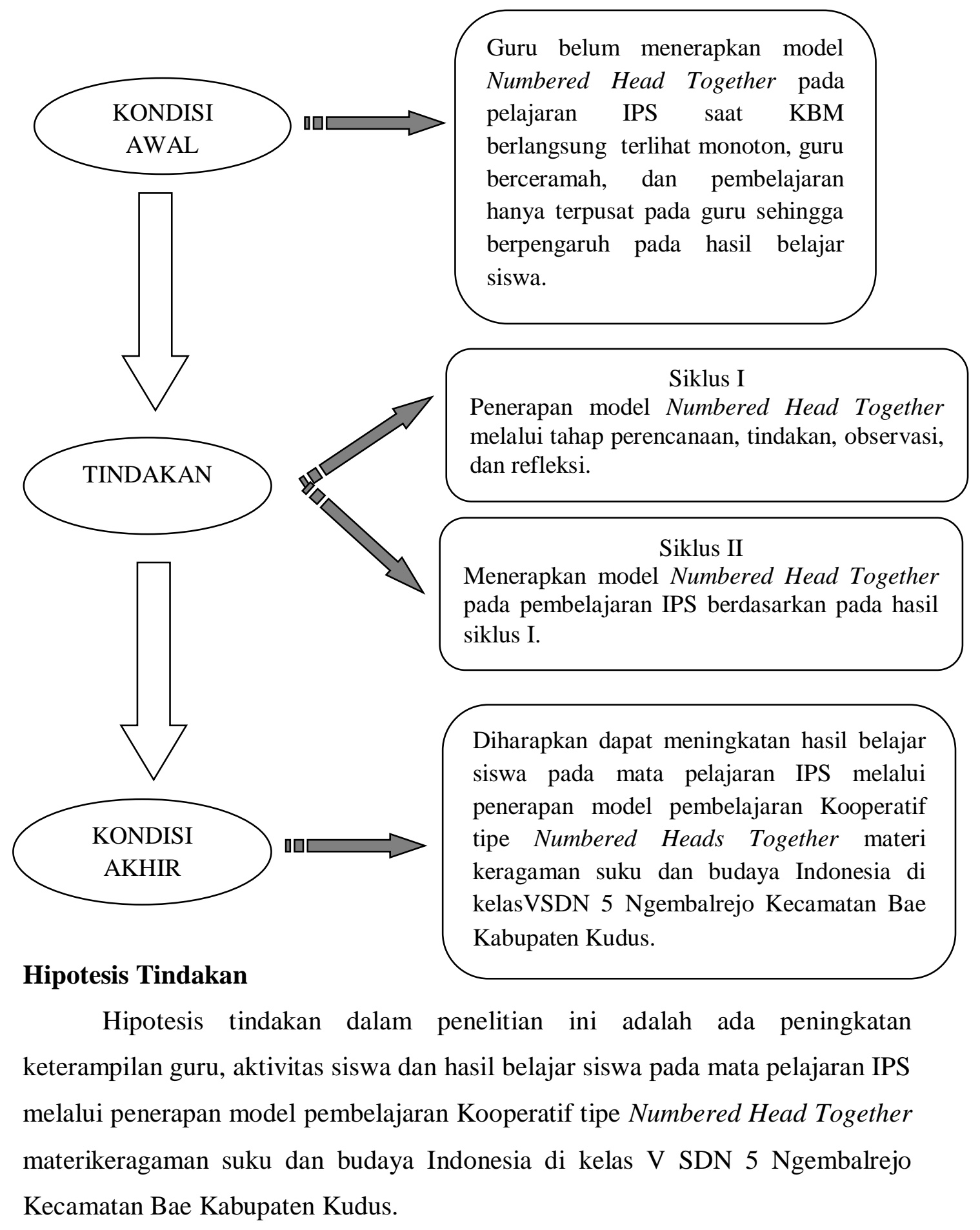




\section{METODE PENELITIAN}

Penelitian Tindakan Kelas ini dilakukan di SDN 5 Ngembalrejo terhadap siswa kelas V pada mata pelajaran IPS materi keragaman suku dan budaya Indonesia. Penelitian ini dibantu oleh guru kelas $\mathrm{V}$ yang bertindak sebagai pengamat (observer) yang bertugas memberi masukan terhadap kekurangan dalam proses penelitian yang dilakukan.

Jenis penelitian yang digunakan dalam penelitian ini adalah Penelitian Tindakan Kelas (PTK). Aqib, dkk (2011: 3) menjelaskan penelitian tindakan kelas adalah penelitian yang dilakukan oleh guru di kelasnya sendiri melalui refleksi diri dengan tujuan untuk memperbaiki kinerjanya sehingga hasil belajar siswa menjadi meningkat. Kegiatan penelitian berangkat dari permasalahan riil yang dihadapi oleh guru dalam proses belajar mengajar, kemudian direfleksikan alternatif pemecahan masalahnya dan ditindaklanjuti dengan tindakan-tindakan nyata yang terencana dan terukur. Desain penelitian ini menggunakan model Kemmis dan Mc Taggart.

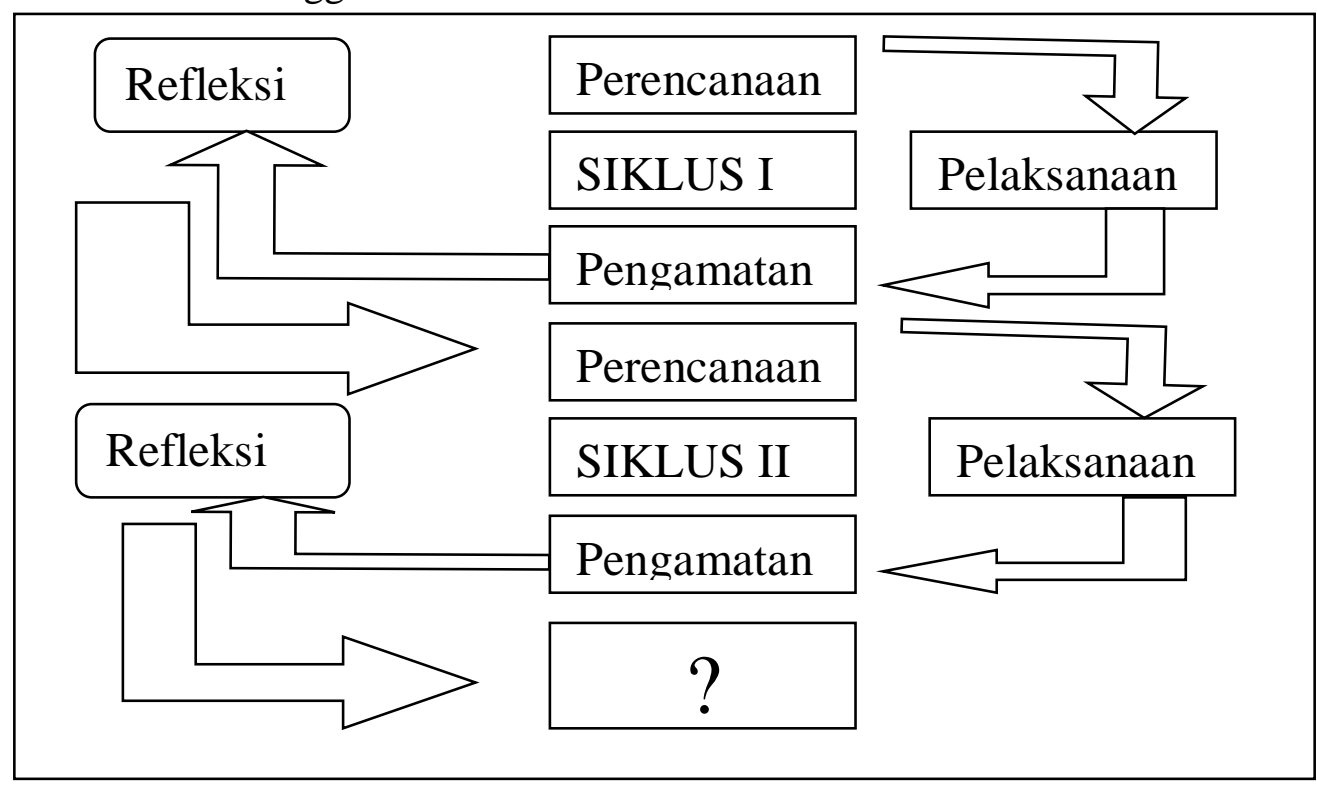

Model Siklus Pelaksanaan Penelitian Kemmis dan Mc Taggart (Arikunto, 2010: 137)

Penelitian ini dilaksanakan di kelas V SDN 5 Ngembalrejo Kudus pada semester I. Penelitian ini dilakukan selama 8 bulan yaitu dimulai dari Agustus 2013 sampai Maret 2014. Subjek penelitian ini adalah siswa kelas V SDN 5 
Ngembalrejo yang berjumlah 25 siswa, terdiri atas 13 siswa perempuan dan 12 siswa laki-laki.

Metode pengumpulan data yang digunakan dalam penelitian ini yaitu metode wawancara, tes, dokumentasi, observasi dan catatan lapangan. Analisis data yang digunakan adalah data kuantutatif yang berbentuk angka-angka dan data kualitatif yang dinyatakan dalam kata-kata atau simbol.

Dalam penelitian diperlukan suatu alat instrumen yang tepat sehingga data yang diperoleh sesuai dengan keadaan yang ada di lapangan. Menurut Purwanto (2013: 56) instrumen adalah alat ukur yang digunakan untuk mengukur dalam rangka pengumpulan data. Hasil atau data penelitian sangat tergantung pada jenis alat (instrumen) pengumpulan datanya. Dalam penelitian ini instrumen yang digunakan adalah pedoman wawancara, tes, observasi.

\section{HASIL PENELITIAN DAN PEMBAHASAN}

\section{Peningkatan Hasil Belajar Kognitif IPS dengan Menggunakan Model Kooperatif Tipe Numbered Heads Together (NHT)}

Hasil pelaksanaan tindakan dengan model pembelajaran kooperatif tipe Numbered Heads Together (NHT) pada pembelajaran IPS siswa kelas V SDN 5 Ngembalrejo mengalami peningkatan hasil belajar dari pra siklus, siklus I sampai siklus II. Pada pra siklus menunjukkan rata-rata nilai hasil belajar IPS 61,16 dengan ketuntasan belajar klasikal 32\%.

Pada siklus I menunjukkan rata-rata nilai hasil belajar sebesar 70,2 dengan ketuntasan belajar klasikal 64\%. Sedangkan pada siklus II, hasil belajar siswa menunjukkan peningkatan nilai rata-rata kelas 73,6 dengan ketuntasan belajar klasikal $88 \%$. Secara ringkas, peningkatan rata-rata nilai hasil belajar IPS siswa kelas V SDN 5 Ngembalrejo sebagai berikut, ketuntasan belajar klasikal siswa pra siklus 32\%, siklus I 64\%, dan siklus II 88\%. Persentase ketuntasan belajar klasikal siswa mengalami peningkatan dari pra siklus ke siklus sebesar $32 \%$, dari siklus I ke siklus II terjadi peningkatan sebesar $24 \%$. 


\section{Aktivitas Belajar Siswa dalam Pembelajaran IPS}

Hasil pelaksanaan tindakan pada pembelajaran IPS menggunakan model pembelajaran kooperatif tipe Numbered Heads Together (NHT) menunjukkan aktivitas belajar IPS siswa sebagai tolok ukur hasil belajar aspek afektif dan psikomotorik dari satu siklus ke siklus berikutnya mengalami peningkatan skor rata-ratanya. Dalam pembelajaran menggunakan model pembelajaran Numbered Heads Together (NHT) dapat melatih siswa untuk bekerjasama dan tanggung jawab siswa serta membuat suasana pembelajaran IPS menjadi menyenangkan.

Dari hasil perhitungan lembar observasi aktivitas belajar IPS siswa pada siklus I pertemuan I diperoleh skor rata-rata 2,40 dengan kategori pembelajaran cukup baik. Sedangkan pada pertemuan II, skor rata-rata yang diperoleh menjadi 2,50, dengan kategori pembelajaran tetap cukup baik. Adanya peningkatan dari siklus I ke siklus II. Dari hasil observasi pada siklus I pertemuan I dan II, apabila di rata-rata, maka pada siklus I skor rata-rata aktivitas belajar siswa yaitu 2,45, dengan kategori cukup baik. Selanjutnya adalah hasil observasi aktivitas belajar siswa pada siklus II, pertemuan I diperoleh skor rata-rata 2,60 dengan kategori pembelajaran baik. Sedangkan pada pertemuan II, skor rata-rata yang diperoleh menjadi 2,69 dengan kategori pembelajaran baik. Adanya peningkatan dari siklus I ke siklus II hasil dari pertemuan I dan II diperoleh skor rata-rata aktivitas belajar siswa sebesar 2,64, dengan kriteria baik. Aktivitas belajar siswa menunjukkan adanya peningkatan skorrata-rata dari siklus I, yaitu dari 2,45 menjadi 2,64 dengan kenaikan sebesar 0,19.

Berdasarkan uraian diatas dapat disimpulkan bahwa ada peningkatan aktivitas belajar siswa kelas V SDN 5 Ngembalrejo melalui penerapan model pembelajaran kooperatif tipe Numbered Heads Together (NHT). Peningkatan hasil belajar siswa tersebut terlihat dalam 3 ranah pembelajaran, yaitu kognitif, afektif, dan psikomotor. Pada ranah kognitif, peningkatan siswa terbukti dengan meningkatkan nilai rata-rata siswa dari siklus I ke siklus II. Kemudian peningkatan hasil belajar siswa juga dapat dibuktikan dengan ranah afektif dan psikomotor. Pembuktian peningkatan hasil belajar siswa pada ranah afektif dan 
psikomotor dapat dilihat dari aktivitas belajar siswa dan aktivitas guru yang mengalami peningkatan pada setiap siklusnya.

\section{Keterampilan Guru dalam Pembelajaran IPS dengan Model Kooperatif Tipe NHT}

Hasil penelitian tindakan kelas menggunakan model pembelajaran kooperatif tipe Numbered Heads Together (NHT) pada pengelolaan pembelajaran guru mengalami peningkatan dari siklus I ke siklus II. Hasil observasi aktivitas guru pada siklus I pertemuan I, diperoleh skor rata-rata 2,70 dengan kriteria pengelolaan pembelajaran baik. Kemudian pada pertemuan II, skor rata-rata yang diperoleh meningkat menjadi 2,94 dengan kriteria pengelolaan pembelajaran baik. Hasil observasi aktivitas guru dapat disimpulkan bahwa skor rata-rata pengelolaan pembelajaran pada siklus I sebesar 2,82 dengan kriteria pengelolaan pembelajaran baik.

Kemudian hasil observasi aktivitas guru siklus pada siklus II pertemuan I, diperoleh skor rata-rata 3,05 dengan kriteria pengelolaan pembelajaran sangat baik. Sedangkan pada pertemuan II, terjadi peningkatan skor rata-rata menjadi 3,11 dengan kriteria pengelolaan pembelajaran sangat baik. Berdasarkan hasil observasi yang diperoleh pada siklus II dapat disimpulkan bahwa skor rata-rata pada siklus II sebesar 3,08 dengan kriteria pengelolaan pembelajaran sangat baik.

Berdasarkan penjelasan dan uraian diatas dapat disimpulkan bahwa hasil observasi pengelolaan pembelajaran guru dengan model pembelajaran kooperatif tipe Numbered Heads Together (NHT) diperoleh kriteria sangat baik sehingga dapat meningkatkan hasil belajar dan aktivitas belajar siswa kelas V SDN 5 Ngembalrejo Bae Kudus

Kemudian dalam penelitian tindakan ini, peneliti juga menggunakan alat peraga/media pembelajaran yang berupa gambar sebagai alat bantu didalam mengajar. Gunawan (2011: 51) menjelaskan bahwa komponen penting lainnya dalam pembelajaran IPS adalah komponen media pembelajaran, media pembelajaran akan mencegah timbulnya verbalisme atau kesalahpahaman siswa terhadap materi yang disampaikan, selain itu media pembelajaran juga akan 
menjadikan siswa menjadi lebih aktif, karena siswa pasti ingin terlibat langsung dalam proses pembelajaran. Untuk usia anak sekolah dasar, gambar merupakan media yang tepat yang dapat digunakan untuk memancing rasa ingin tahu siswa terhadap sesuatu.

\section{PENUTUP}

\section{SIMPULAN}

Berdasarkan hasil penelitian tindakan kelas yang dilaksanakan di kelas V SDN 5 Ngembalrejo Kecamatan Bae Kabupaten Kudus dapat diperoleh kesimpulan sebagai berikut:

1. Peningkatan hasil belajar aspek kognitif dapat dilihat dari nilai rata-rata siswa yang meningkat dari siklus I ke siklus II. Nilai rata-rata yang diperoleh pada kondisi pra siklus sebesar 61,1 , naik menjadi 70,2 pada siklus I, dan pada siklus II naik lagi menjadi 73,8. Adapun persentase ketuntasan hasil belajar pada pra siklus sebesar $32 \%$, pada siklus I naik menjadi $64 \%$, dan pada siklus II naik lagi menjadi $88 \%$.

2. Peningkatan hasil belajar pada aspek afektif dan psikomotor terlihat pada aktivitas belajar siswa, setelah diterapkannya model kooperatif tipe Numbered Heads Together pada siklus I skor rata-rata aktivitas belajar siswa sebesar 2,45 dengan kriteria baik, pada siklus II skor rata-rata aktivitas belajar siswa meningkat menjadi 2,65 dengan kriteria tetap baik.

3. Hasil observasi aktivitas guruskor rata-rata pengelolaan pembelajaran pada siklus I sebesar 2,82. Kemudian hasil observasi aktivitas guru siklus pada siklus II diperoleh skor rata-rata pada siklus II sebesar 3,08.

\section{SARAN}

\section{Bagi Siswa}

Penerapan model pembelajaran yang tepat mampu menumbuhkan semangat kerjasama antarsiswa, meningkatkan motivasi, dan daya tarik siswa terhadap pembelajaran terutama pada mata pelajaran Ilmu Pengetahuan Sosial (IPS). 


\section{Bagi Guru}

a) Dalam proses pembelajaran guru perlu menerapkan suatu model pembelajaran untuk menciptakan kondisi belajar yang menarik dan menyenangkan. Dengan cara seperti itu maka guru akan lebih mampu mengkondisikan kelas dengan lebih baik.

b) Untuk pembelajaran IPS diharapkan model kooperatif tipe Numbered Heads Together dapat digunakan sebagai masukan bagi guru dalam pelaksanaan pembelajaran yang tepat dalam rangka meningkatkan hasil belajar siswa, khususnya mata pelajaran Ilmu Pengetahuan Sosial.

\section{Bagi Sekolah}

Hendaknya dapat memotivasi guru untuk dapat meningkatkan kualitas pembelajaran dengan menerapkan model-model pembelajaran yang menarik dan inovatif seperti model pembelajaran kooperatif tipe Numbered Heads Together (NHT).

\section{DAFTAR PUSTAKA}

Aqib, Zainal, dkk. 2011. Penelitian Tindakan Kelas untuk Guru SD, SLB, dan TK. Bandung: Yrama Widya

Arikunto, Suharsimi. 2008. Penelitian Tindakan Kelas. Jakarta: Bumi Aksara

Aunurrahman. 2009. Belajar Dan Pembelajaran. Bandung: Alfabeta

Djamarah, Syaiful Bahri. 2010. Guru \& Anak Didik Dalam Interaksi Edukatif Suatu Pendekatan Teoritis Psikologis. Jakarta: Rineka Cipta

Gunawan, Rudy. 2011. Pendidikan IPS: Filosofi, Konsep, Dan Aplikasi. Bandung: Alfabeta

Hamdani. 2011. Strategi Belajar Mengajar. Bandung: Pustaka Setia

Huda, Miftahul. 2013. Cooperative Learning Metode, Teknik, Struktur dan Model Penerapan. Yogyakarta : Pustaka Pelajar 
Koentjaraningrat. 2009. Pengantar Ilmu Antropologi. Jakarta: Rineka Cipta

Purwanto. 2013. Evaluasi Hasil Belajar. Yogyakarta: Pustaka Pelajar

Ranjabar, Jacobus. 2006. Sistem Sosial Budaya Indonesia Suatu Pengantar. Bogor: Ghalia Indonesia

Riyanto, Yatim. 2010. Paradigma Baru Pembelajaran Sebagai Referensi bagi Pendidik dalam Implementasi Pembelajaran yang Efektif dan Berkualitas. Jakarta: Kencana

Setiadi, M. Elly, dkk. 2006. Ilmu Sosial \& Budaya Dasar. Jakarta: Kencana

Slameto. 2010. Belajar \& Faktor-Faktor Yang Mempengaruhinya. Jakarta: Rineka Cipta

Solihatin, Etin dan Raharjo. 2011. Cooperative Learning Analisis Model Pembelajaran IPS. Jakarta: Bumi Aksara

Suprijono, Agus. 2013. Cooperative Learning Teori \& Aplikasi Paikem.Yogyakarta: Pustaka Pelajar.

Syah, Muhibbin. 2012. Psikologi Belajar. Jakarta: PT. Raja Grafindo Persada.

Trianto. 2010. Mendesain Model Pembelajaran Inovatif-Progresif Konsep, Landasan Dan Implementasinya Pada Kurikulum Tingkat Satuan Pendidikan (KTSP). Jakarta: Kencana.

Widagdho, Djoko. 2001. Ilmu Budaya Dasar. Jakarta: Bumi Aksara 